\title{
Research Article \\ Effects of Drought on Morphological Traits in Some Cowpea Genotypes by Evaluating Their Combining Abilities
}

\author{
Amos Afolarin Olajide and Christopher Olumuyiwa Ilori \\ Department of Crop Protection and Environmental Biology, University of Ibadan, Ibadan, Nigeria \\ Correspondence should be addressed to Amos Afolarin Olajide; olamosfolarin@yahoo.com
}

Received 30 May 2017; Accepted 14 August 2017; Published 20 September 2017

Academic Editor: Othmane Merah

Copyright ( 2017 Amos Afolarin Olajide and Christopher Olumuyiwa Ilori. This is an open access article distributed under the Creative Commons Attribution License, which permits unrestricted use, distribution, and reproduction in any medium, provided the original work is properly cited.

\begin{abstract}
An evaluation was conducted to understand the genetic effects of combining ability for four different morphological traits, on 42 hybrids in randomized complete block design with three replications in water-stressed and well-watered environments. The significance of the additive variance (D) and dominance variance $\left(\mathrm{H}_{1}\right)$ indicated the presence of both additive and nonadditive gene actions in both environments. Among the parents, there was asymmetrical distribution of positive and negative dominant genes and the preponderance of overdominance gene action for all the traits in both environments. This study also indicated a minimum of ten genes for plant height in water-stressed environment and minimum of three and eight genes for terminal leaflet area and number of leaves per plant in both environments, respectively. Estimates of narrow-sense heritability ranged from $13.0 \%$ for number of branches per plant in water-stressed to $95.0 \%$ in well-watered environment for terminal leaflet area. The study revealed that Danilla, IT93K-432-1, and IT97K-499-35 were the best general combiners for all traits, Danilla $\times$ IT97K-499-35, and Danilla $\times$ IT93K-432-1 were found to be the best specific combiners for all traits in water-stressed environment. Genetic interactions, additive $x$ additive and additive $\times$ dominance, were more pronounced in the inheritance of the traits. This indicated that the selection for these traits should be delayed till advanced generations.
\end{abstract}

\section{Introduction}

Cowpea (Vigna unguiculata (L.) Walp) is a legume of African origin (Baghizadeh et al. [1]). It is a legume annual crop that thrives in warm conditions. It is being cultivated in the tropics and in subtropics during the warm season (Hall et al. [2], Valenzuela and Smith [3], Noubissié et al. [4], and Abadassi [5]). Poor people in less developed countries of the tropics derived their protein, animal feed, and cash income from the production of the crop (Diouf [6]). FAOSTAT [7] reported that most cowpeas are grown in the African continent, particularly in Nigeria and Niger which account for $66 \%$ of world cowpea production. FAOSTAT [8] earlier estimated the worldwide production at 10 million hectares, while Nigeria and Niger produced 3.04 and 0.69 million tonnes seed of the crop, respectively (Quinn and Myers [9]). These two countries alone account for more than $81 \%$ of the world crop (FAOSTAT [8]). Cowpea as a species is considered to be moderately tolerant to water stress, particularly the spreading cultivars (Shimelis and Shiringani [10] and Hayatu et al. [11].) There is considerable intercultivar variation in the tolerance to water stress (Summerfield et al. [12]). Precipitation of around $50 \mathrm{~mm}$ per month is considered to be sufficient for crop growth in soil with good water holding capacity. However, International Institute of Tropical Agriculture [13] and Ishiyaku and Aliyu [14] reported that drought is a major constraint in semiarid tropics due to erratic rainfall in the beginning and towards the end of rainy season. The crop is often subjected to drought stress in both seedling and terminal growth stages which cause the substantial reduction in grain yield as well as biomass production. Hence the necessity of effective breeding program would support high yielding and well-adapted varieties for water deficit conditions. Simultaneous selections in water-stressed and nonwaterstressed environments for nonwater-stressed yield and waterstressed stability will achieve the desired goals of evolving high yielding drought-tolerant genotypes (Ishiyaku and Aliyu [14]). Understanding the genetic mechanism involved in the 
TABLE 1: Characteristics of cowpea genotypes used.

\begin{tabular}{lcccc}
\hline Parent & Genotypes & Origin & Growth habit & Level of drought tolerance \\
\hline $\mathrm{P}_{1}$ & Danilla & Landrace & Semispreading & High tolerance of drought \\
$\mathrm{P}_{2}$ & IT92KD-357-3 & IITA & Semispreading & Tolerance of drought \\
$\mathrm{P}_{3}$ & TVU7778 & IITA & Erect & Highly susceptible to drought \\
$\mathrm{P}_{4}$ & TVU12349 & IITA & Erect & Moderate tolerance of drought \\
$\mathrm{P}_{5}$ & IT93K-432-1 & IITA & Erect & Tolerance of drought \\
$\mathrm{P}_{6}$ & IT97K-499_35 & IITA & Erect & High tolerance of drought \\
$\mathrm{P}_{7}$ & IT89KD-288 & IITA & Semispreading & Moderate tolerance of drought \\
$\mathrm{P}_{8}$ & IT98K-205-8 & IITA & Erect & Highly susceptible to drought \\
$\mathrm{P}_{9}$ & IT98K-491-4 & IITA & Erect & Very moderate tolerance of drought \\
$\mathrm{P}_{10}$ & IT99K-513-21 & IITA & Spreading & Tolerance of drought \\
\hline
\end{tabular}

inheritance of a particular trait will help the plant breeder in effective selection and selecting for the best traits that would contribute to better yield. Combining ability study provides information on the genetic mechanisms controlling quantitative traits and enables breeder to select suitable parents for further improvement (Hira Lal et al. [15] and Kadam et al. [16]). General combining ability is a good measure of additive gene action, whereas specific combining ability is a measure of nonadditive gene action (Rojas and Sprague [17]). The problem of water stress can be solved by developing drought-tolerant genotypes. Erratic rainfall caused by climate change has become a threatening factor to crop production in Nigeria. The areas that are supposed to be rainforest zones are gradually becoming savannah belts and the desert is advancing at fast rate towards the southwest part of Nigeria from the North. This is resulting in a real problem in the farming community creating joblessness. However, breeding along with better crop management has a major role to play in meeting the changes in the global climate change. Therefore the objective of this study was to evaluate the general and specific combining ability of some morphological characteristics in cowpea aimed to develop cowpea genotypes with increased drought tolerance.

\section{Materials and Methods}

This research was conducted at the Teaching and Research Farm of the University of Ibadan. University of Ibadan is located at latitude $07^{0} 34^{1}$ and $03^{0} 54^{1} \mathrm{E}$ at an altitude of $220 \mathrm{~m}$. Soil type is Alfisols of Egbeda and Gambari soil series. The ten cowpea genotypes of diverse drought tolerance used were collections maintained by Genetic Resources Unit, International Institute of Tropical Agriculture, Ibadan, Nigeria. The cowpea genotypes planted were as follows: Danilla, IT93K452, IT97K-499-35, IT89KD-288, IT98K-205-8, TVU7778, TVU12349, IT92KD-357-2, IT98K-491-4, and IT99K-573-2-1. From screening experiment, crosses in a diallel design involving the ten parental lines, with diverse drought tolerance, were selected for diallel analysis. Hybridization method was carried out to obtain a total of 42 hybrid combinations following partial diallel mating design. Parental lines and $21 \mathrm{~F}_{1}$ and $21 \mathrm{RF}_{1}$ hybrids were selected for evaluation in a randomized complete block design with three replications at Teaching and
Research Farm, University of Ibadan, during the dry season, November to February 2011/2012 and 2012/2013. Each entry was grown in a single row plot $3 \mathrm{~m}$ long with row spacing $75 \mathrm{~cm}$ apart and plant spacing $20 \mathrm{~cm}$ within a row. Two seeds were sown per hole which was later thinned to one seed per hole.

After sowing, all the plants were watered until the emergence of the trifoliolate leaves after which watering was suspended on water-stressed plots. The water level was devised by irrigating the plots with supplemental water whenever required, while on the other plot it was completely held throughout the growing season. The soil moisture content of the plots was also estimated on regular basis. Crop management was uniform following recommended production package. Data were collected on plant height, terminal leaflet area, the number of leaves per plant, and number of branches per plant at six weeks after planting. Ten plants for each parent, $F_{1}$, and $\mathrm{RF}_{1}$, were sampled per replication. Data collected on parental lines and the hybrids for all the traits instudy were averaged and utilized for statistical analysis. Combining ability analysis was carried out following model II of Method 1 modified for partial diallel cross (parents and $\mathrm{F}_{1}$ and $\mathrm{RF}_{1}$ ) for combining ability analysis of Griffing [18]. The various genetic components were calculated based on the formulae of Hayman [19] as demonstrated by Aksel and Johnson [20].

\section{Results}

3.1. Combining Ability Analysis. Table 1 showed the descriptions of parental cowpea genotypes used. Analysis of variance for combining ability (Table 2) showed highly significant differences in both general combining ability (GCA) and specific combining ability (SCA) of the cowpea lines for the entire traits indicating the importance of both additive and nonadditive gene effects in their inheritance in both environments.

3.2. General Combining Ability Effect. The estimates of GCA effect of the parents are furnished in Table 3. All the parental lines except IT99K-513-21 exhibited significant GCA for plant height at six weeks in well-watered environment, while IT98K-205-8 and IT99K-513-21 only were not significant 
TABLE 2: Analysis of variance of diallel cross for morphological characteristics of cowpea crosses in water-stressed (WS) and well-watered (WW) environments.

\begin{tabular}{|c|c|c|c|c|c|c|c|c|c|}
\hline \multirow{2}{*}{ Source } & \multirow{2}{*}{$\mathrm{df}$} & \multicolumn{2}{|c|}{$\mathrm{PH}(\mathrm{cm})$} & \multicolumn{2}{|c|}{ TLA $(\mathrm{cm} 2)$} & \multicolumn{2}{|c|}{ NL } & \multicolumn{2}{|c|}{ NB } \\
\hline & & WW & WS & WW & WS & WW & WS & WW & WS \\
\hline Genot. & 51 & $202.7^{*}$ & $51.1^{*}$ & $320.3^{*}$ & $159.7^{*}$ & $304.1^{*}$ & $74.1^{*}$ & $2.2^{*}$ & $1.0^{*}$ \\
\hline Replic & 2 & $33.4^{*}$ & $3.8^{\mathrm{ns}}$ & $16.0^{\mathrm{ns}}$ & $0.94^{\mathrm{ns}}$ & $67.9^{\mathrm{ns}}$ & $3.9^{\mathrm{ns}}$ & $0.41^{\mathrm{ns}}$ & $0.49^{*}$ \\
\hline Parent & 9 & $530.2^{*}$ & $27.3^{*}$ & $381.8^{*}$ & $292.6^{*}$ & $703.5^{*}$ & $20.4^{*}$ & $1.7^{*}$ & $0.55^{*}$ \\
\hline $\mathrm{F}_{1}$ & 20 & $114.8^{*}$ & $51.5^{*}$ & $245.8^{*}$ & $119.9^{*}$ & $231.4^{*}$ & $55.4^{*}$ & $2.6^{*}$ & $0.64^{*}$ \\
\hline $\mathrm{RF}_{1}$ & 20 & $139.9^{*}$ & $36.6^{*}$ & $390.5^{*}$ & $140.1^{*}$ & $174.2^{*}$ & $89.0^{*}$ & $2.1^{*}$ & $1.34^{*}$ \\
\hline $\mathrm{PvF}_{1}$ & 1 & $247.1^{*}$ & $454.3^{*}$ & $20.3^{*}$ & $467.8^{*}$ & $371.9^{*}$ & $516.7^{*}$ & $0.9^{*}$ & $0.09^{\mathrm{ns}}$ \\
\hline $\mathrm{PvRF}_{1}$ & 1 & $486.6^{*}$ & $610.4^{*}$ & $35.9^{*}$ & $209.9^{*}$ & $1050.7^{*}$ & $749.3^{*}$ & $0.03^{\mathrm{ns}}$ & $2.9^{*}$ \\
\hline Error & 102 & 3.50 & 2.91 & 11.45 & 6.92 & 35.50 & 3.19 & 0.26 & 0.17 \\
\hline GCA & 9 & $781.0^{*}$ & $354.3^{*}$ & $1824.2^{*}$ & $668.7^{*}$ & $388.7^{*}$ & $172.7^{*}$ & $9.9^{*}$ & $19.9^{*}$ \\
\hline SCA & 20 & $7114^{*}$ & $1602^{*}$ & $276251.5^{*}$ & $76968.7^{*}$ & $53523.9^{*}$ & $4279.3^{*}$ & $88.2^{*}$ & $243.9^{*}$ \\
\hline RCA & 20 & $82.0^{*}$ & $7.05^{*}$ & $32.2^{*}$ & $34.9^{*}$ & $75.4^{*}$ & $8.9^{*}$ & $0.4^{*}$ & $0.8^{*}$ \\
\hline Error & 102 & 3.50 & 2.91 & 11.45 & 6.9 & 35.50 & 3.19 & 0.17 & 0.26 \\
\hline
\end{tabular}

*: significant; ns: not significant; PH6: plant height at six weeks; TLA: terminal leaflet area; NL: number of leaves per plant; and NB: number of branches per plant.

TABLE 3: General combining ability effects of morphological characteristics of ten cowpea genotypes in water-stressed (WS) and well-watered (WW) environments.

\begin{tabular}{|c|c|c|c|c|c|c|c|c|}
\hline \multirow{2}{*}{ Parents } & \multicolumn{2}{|c|}{$\mathrm{PH}(\mathrm{cm})$} & \multicolumn{2}{|c|}{ TLA $(\mathrm{cm} 2)$} & \multicolumn{2}{|c|}{$\mathrm{NL}$} & \multicolumn{2}{|c|}{ NB } \\
\hline & WW & WS & WW & WS & WW & WS & WW & WS \\
\hline Danilla & $4.8^{*}$ & $3.2^{*}$ & $6.7^{*}$ & $3.0^{*}$ & $2.4^{\mathrm{ns}}$ & $2.9^{*}$ & $0.7^{*}$ & $0.6^{*}$ \\
\hline IT92KD-357-3 & $3.7^{*}$ & $2.8^{*}$ & $6.9^{*}$ & $6.2^{*}$ & $2.4^{*}$ & $2.1^{*}$ & $0.6^{*}$ & $0.6^{*}$ \\
\hline TVU7778 & $4.9^{*}$ & $2.4^{*}$ & $2.3^{*}$ & $1.9^{*}$ & $1.5^{\mathrm{ns}}$ & $0.4^{\mathrm{ns}}$ & $0.8^{*}$ & $0.6^{*}$ \\
\hline TVU12349 & $-8.2^{*}$ & $-5.2^{*}$ & $-10.3^{*}$ & $-7.2^{*}$ & $-6.8^{*}$ & $-3.5^{*}$ & $-1.5^{*}$ & $-1.0^{*}$ \\
\hline IT93K-432-1 & $3.9^{*}$ & $2.8^{*}$ & $4.9^{*}$ & $2.3^{*}$ & $5.5^{*}$ & $1.2^{*}$ & $0.4^{*}$ & $0.3^{*}$ \\
\hline IT97K-499_35 & $8.9^{*}$ & $6.3^{*}$ & $14.6^{*}$ & $7.8^{*}$ & $5.5^{*}$ & $4.8^{*}$ & $1.2^{*}$ & $0.9^{*}$ \\
\hline IT89KD-288 & $-9.4^{*}$ & $-5.3^{*}$ & $-16.3^{*}$ & $-8.9^{*}$ & $-4.4^{*}$ & $-4.4^{*}$ & $-1.6^{*}$ & $-0.9^{*}$ \\
\hline IT98K-205-8 & $-2.1^{*}$ & $-0.52^{\mathrm{ns}}$ & $1.1^{\mathrm{ns}}$ & $1.2^{*}$ & $-1.9^{\mathrm{ns}}$ & $-0.3^{\mathrm{ns}}$ & $-0.1^{\mathrm{ns}}$ & $-0.2^{\mathrm{ns}}$ \\
\hline IT98K-491-4 & $-7.1^{*}$ & $-5.8^{*}$ & $-10.6^{*}$ & $-7.0^{*}$ & $-5.4^{*}$ & $-2.9^{*}$ & $-0.9^{*}$ & $-0.8^{*}$ \\
\hline IT99K-513-21 & $0.1^{\mathrm{ns}}$ & $-0.6^{\mathrm{ns}}$ & $0.7^{\mathrm{ns}}$ & $0.8^{\text {ns }}$ & $1.3^{\mathrm{ns}}$ & $-0.4^{\mathrm{ns}}$ & $0.3^{*}$ & $0.1^{\mathrm{ns}}$ \\
\hline S.E & 0.40 & 0.36 & 0.72 & 0.56 & 1.26 & 0.38 & 0.09 & 0.11 \\
\hline
\end{tabular}

*: significant; ns: not significant.

in water-stressed environment. However, IT97K-499-35 had high positive significant GCA effect and thus good general combiners for plant height in both environments. On the contrary, TVU12349, IT89KD-288, and IT98K-491-4 had high negative and significant GCA effect and were, therefore, poor combiners for plant height in both environments. Danilla had intermediate GCA effect in both environments, while IT99K513-21 was also poor combiners in both environments.

With respect to terminal leaflet area, the estimates of GCA effect indicated that IT97K-499-35, Danilla, and IT92KD357-3 had high positive significant GCA effect and thus were good combiners in well-watered environment, while TVU12349, IT89KD-288, and IT98K-491-4 had high negative GCA and therefore poor combining ability for plant leaflet area in nonwater-stressed environment. However, IT92KD357-3 and IT97K-499-35 had high positive GCA effect and thus good combiners in water-stressed environment, while
TVU12349, IT89KD-288, and IT98K-491-4 had negative significant GCA effect and, therefore, were poor combiners for plant leaflet area in water-stressed environment.

With respect to the number of leaves per plant, IT93K432-1 and IT97K-499-35 had positive significant GCA effect and therefore were good combiners for number of leaves in well-watered environment, while TVU12349, IT89KD-288, and IT98K-491-4 had negative GCA effect and therefore were poor combiners. TVU7778, IT98K-205-8, and IT99K-513-21 were not significant and therefore were poor combiners in well-watered environment. IT97K-499-35 had high positive significant GCA effect and therefore was good combiners in water-stressed environment, while TVU12349 and IT89KD288 had negative significant GCA effect and thus were poor combiners. IT98K-205-8 and IT99K-513-21 were not significant in water-stressed environment and therefore were poor combiners. 
TABLE 4: Specific combining ability effects for different morphological characteristics in cowpea in water-stressed (WS) and well-watered (WW) environments.

\begin{tabular}{|c|c|c|c|c|c|c|c|c|}
\hline \multirow{2}{*}{ Cross } & \multicolumn{2}{|c|}{$\mathrm{PH}(\mathrm{cm})$} & \multicolumn{2}{|c|}{ TLA $(\mathrm{cm} 2)$} & \multicolumn{2}{|c|}{ NL } & \multicolumn{2}{|c|}{ NB } \\
\hline & WW & WS & WW & WS & WW & WS & WW & WS \\
\hline Danilla $\times$ IT92KD-357-3 & $-10.8^{*}$ & $1.2^{\mathrm{ns}}$ & $-9.2^{*}$ & $0.4^{\mathrm{ns}}$ & $-5.9^{\mathrm{ns}}$ & $-4.2^{*}$ & $-1.9^{*}$ & $-0.01^{\mathrm{ns}}$ \\
\hline Danilla $\times$ Tvu7778 & $2.7^{*}$ & $3.4^{*}$ & $1.1^{\mathrm{ns}}$ & $-0.5^{\mathrm{ns}}$ & $1.4^{\mathrm{ns}}$ & $0.5^{\mathrm{ns}}$ & $0.3^{\text {ns }}$ & $0.2^{\mathrm{ns}}$ \\
\hline Danilla $\times$ IT93K-452-1 & $14.3^{*}$ & $17.2^{*}$ & $14.2^{*}$ & $17.1^{*}$ & $10.9^{*}$ & $9.7^{*}$ & $1.9^{*}$ & $2.5^{*}$ \\
\hline Danilla $\times$ IT97K-499-35 & $9.9^{*}$ & $6.9^{*}$ & $8.4^{*}$ & $13.0^{*}$ & $2.4^{\mathrm{ns}}$ & $6.7^{*}$ & $0.4^{\mathrm{ns}}$ & $1.2^{*}$ \\
\hline Danilla $\times$ IT98K-205-8 & $5.6^{*}$ & $0.8^{\mathrm{ns}}$ & $25.2^{*}$ & $10.9^{*}$ & $7.8^{*}$ & $-1.5^{\mathrm{ns}}$ & $1.3^{*}$ & $-0.1^{\mathrm{ns}}$ \\
\hline Danilla $\times$ IT98K-491-4 & $6.2^{*}$ & $2.4^{*}$ & $10.8^{*}$ & $14.9^{*}$ & $5.5^{\mathrm{ns}}$ & $8.9^{*}$ & $1.9^{*}$ & $1.5^{*}$ \\
\hline IT92KD-357-3 × Tvu7778 & $-3.1^{*}$ & $-1.3^{\mathrm{ns}}$ & $2.8^{\mathrm{ns}}$ & $-0.6^{\mathrm{ns}}$ & $-0.8^{\mathrm{ns}}$ & $-1.1^{\mathrm{ns}}$ & $0.2^{\mathrm{ns}}$ & $0.6^{\mathrm{ns}}$ \\
\hline IT92KD-357-3 × IT93K-452-1 & $5.7^{*}$ & $11.5^{*}$ & $16.8^{*}$ & $14.6^{*}$ & $-2.4^{\mathrm{ns}}$ & $9.5^{*}$ & $1.2^{*}$ & $1.5^{*}$ \\
\hline IT92KD-357-3 × IT97K-499-35 & $1.5^{*}$ & $7.1^{*}$ & $-10.2^{*}$ & $4.4^{*}$ & $7.7^{*}$ & $7.3^{*}$ & $-0.1^{\mathrm{ns}}$ & $0.8^{*}$ \\
\hline IT92KD-357-3 × IT98K-205-8 & $10.9^{*}$ & $-0.5^{\mathrm{ns}}$ & $5.9^{*}$ & $-4.7^{*}$ & $6.7^{\mathrm{ns}}$ & $-0.2^{\mathrm{ns}}$ & $1.6^{*}$ & $0.4^{\mathrm{ns}}$ \\
\hline IT92KD-357-3 × IT99K-513-21 & $13.7^{*}$ & $13.5^{*}$ & $5.2^{*}$ & $16.5^{*}$ & $15.1^{*}$ & $13.3^{*}$ & $1.9^{*}$ & $2.7^{*}$ \\
\hline Tvu7778 × IT93K-452-1 & $19.9^{*}$ & $2.9^{*}$ & $11.1^{*}$ & $3.2^{\mathrm{ns}}$ & $11.4^{*}$ & $2.5^{*}$ & $1.1^{*}$ & $0.4^{\mathrm{ns}}$ \\
\hline Tvu7778 × IT97K-499-35 & $2.3^{\mathrm{ns}}$ & $3.7^{*}$ & $-3.8^{\mathrm{ns}}$ & $4.7^{*}$ & $0.1^{\mathrm{ns}}$ & $1.5^{\mathrm{ns}}$ & $-0.2^{\mathrm{ns}}$ & $0.2^{\mathrm{ns}}$ \\
\hline Tvu7778 × IT89KD-288 & $11.8^{*}$ & $12.7^{*}$ & $16.7^{*}$ & $14.6^{*}$ & $-1.3^{\mathrm{ns}}$ & $3.9^{*}$ & $2.3^{*}$ & $2.1^{*}$ \\
\hline Tvu7778 × IT99K-513-21 & $3.9^{*}$ & $4.1^{*}$ & $21.9^{*}$ & $15.0^{*}$ & $10.2^{*}$ & $4.1^{*}$ & $1.5^{*}$ & $2.2^{*}$ \\
\hline Tvu12349 × IT97K-499-35 & $19.3^{*}$ & $10.9^{*}$ & $33.8^{*}$ & $13.9^{*}$ & $13.5^{*}$ & $9.1^{*}$ & $2.3^{*}$ & $1.2^{*}$ \\
\hline IT93K-452-1 × IT97K-499-35 & $-3.9^{*}$ & $3.9^{*}$ & $2.4^{\mathrm{ns}}$ & $1.1^{\mathrm{ns}}$ & $-4.1^{\mathrm{ns}}$ & $4.3^{*}$ & $0.1^{\mathrm{ns}}$ & $0.9^{*}$ \\
\hline IT93K-452-1 × IT99K-513-21 & $10.8^{*}$ & $6.7^{*}$ & $24.9^{*}$ & $14.9^{*}$ & $3.0^{\mathrm{ns}}$ & $2.5^{*}$ & $1.6^{*}$ & $1.2^{*}$ \\
\hline IT97K-499-35 × IT98K-205-8 & $10.8^{*}$ & $5.7^{*}$ & $31.2^{*}$ & $2.7^{\mathrm{ns}}$ & $8.2^{*}$ & $2.9^{*}$ & $-0.3^{\mathrm{ns}}$ & $0.2^{\mathrm{ns}}$ \\
\hline IT97K-499-35 × IT98K-491-4 & $10.7^{*}$ & $5.9^{*}$ & $25.6^{*}$ & $8.9^{*}$ & $7.5^{\mathrm{ns}}$ & $1.4^{\mathrm{ns}}$ & $2.7^{*}$ & $1.6^{*}$ \\
\hline IT98K-205-8 × IT99K-513-21 & $14.9^{*}$ & $11.3^{*}$ & $20.0^{*}$ & $15.7^{*}$ & $12.9^{*}$ & $7.4^{*}$ & $2.9^{*}$ & $1.4^{*}$ \\
\hline S.E & 1.20 & 1.09 & 2.17 & 1.68 & 3.82 & 1.14 & 0.27 & 0.32 \\
\hline
\end{tabular}

*: significant; ns: not significant.

With respect to number of branches per plant, IT97K499-35 had relatively high significant GCA effect and, therefore, was good combiners in both environments.

3.3. Specific Combining Ability. In Tables 4 and 5, among 42 hybrids observed, Danilla $\times$ IT93K-452-1, Danilla $\times$ IT97K499-35, IT92KD-357-3 × IT98K-205-8, IT92KD-357-3 × IT99K-513-21, Tvu7778 × IT93K-452-1, Tvu7778 × IT89KD288, Tvu12349 × IT97K-499-35, IT93K-452-1 × IT99K-513-21, IT97K-499-35 × IT98K-205-8, and IT98K-205-8 × IT99K513-21 were found to be best specific combiners for plant height as evident from their high significant positive SCA effect in well-watered environment. However, Danilla $\times$ IT93K-452-1, IT92KD-357-3 × IT93K-452-1, IT92KD-357-3 × IT99K-513-21, Tvu7778 × IT89KD-288, Tvu12349 × IT97K499-35, IT98K-205-8 × IT99K-513-21, Danilla $\times$ IT97K499-35, and IT93K-452-1 × IT99K-513-21 were best specific combiners in water-stressed environment for plant height at six weeks. Reciprocal combining ability (RCA) effects indicated the crosses IT93K-452-1 × Danilla, IT97K-499-35 $\times$ Danilla, IT98K-491-4 × Danilla, IT93K-452-1 × Tvu7778, IT97K-499-35 × Tvu7778, IT89KD-288 × Tvu7778, IT97K499-35 × Tvu12349, and IT98K-205-8 × IT97K-499-35 to be highly significant in well-watered environment, while crosses IT93K-452-1 × Tvu7778 and IT97K-499-35 × Tvu7778 were only significant in water-stressed environment.
With respect to terminal leaflet area, Danilla $\times$ IT93K452-1, Danilla $\times$ IT97K-499-35 Danilla $\times$ IT98K-2058, Danilla $\times$ IT98K-491-4, IT92KD-357-3 × IT93K-452-1, Tvu7778 $\times$ IT93K-452-1, Tvu7778 $\times$ IT89KD-288, Tvu7778 $\times$ IT99K-513-21, Tvu12349 × IT97K-499-35, IT93K-452-1 × IT99K-513-21, IT97K-499-35 × IT98K-205-8, IT97K-499$35 \times$ IT98K-491-4, and IT98K-205-8 × IT99K-513-21 had relatively high positive significant SCA effects and therefore were good specific combiners for terminal leaflet area in well-watered environment. In water-stressed environment, Danilla $\times$ IT93K-452-1, Danilla $\times$ IT97K-499-35 Danilla $\times$ IT98K-205-8, Danilla $\times$ IT98K-491-4, IT92KD-357-3 $\times$ IT93K-452-1, IT92KD-357-3 × IT99K-513-21, Tvu7778 × IT89KD-288, Tvu7778 × IT99K-513-21, Tvu12349 × IT97K499-35, IT93K-452-1 × IT99K-513-21, and IT98K-205-8 × IT99K-513-21 were good specific combiners as evident by their positive significant SCA values for terminal leaflet area in water-stressed environment. The RCA effect for terminal leaflet area indicated crosses Tvu7778 $\times$ Danilla, IT93K-452-1 $\times$ Danilla, IT93K-452-1 × Tvu7778, IT89KD-288 × Tvu7778, IT99K-513-21 × IT93K-452-1, and IT99K-513-21 × IT98K$205-8$ to be highly positively significant in nonwater-stressed and IT98K-491-4 × Danilla, IT93K-432-1 × Tvu7778, IT98K205-8 × IT97K-499-35, and IT99K-513-21 × IT98K-205-8 in water-stressed environment.

For number of leaves per plant, Danilla $\times$ IT93K452-1, Danilla $\times$ IT98K-205-8, Tvu7778 × IT99K-513-21, 
TABLE 5: Reciprocal combining ability effects for different morphological characteristics in cowpea in water-stressed (WS) and well-watered (WW) environments.

\begin{tabular}{|c|c|c|c|c|c|c|c|c|}
\hline \multirow{2}{*}{ Cross } & \multicolumn{2}{|c|}{$\mathrm{PH}$} & \multicolumn{2}{|c|}{ TLA } & \multicolumn{2}{|c|}{ NL } & \multicolumn{2}{|c|}{ NB } \\
\hline & WW & WS & WW & WS & WW & WS & WW & WS \\
\hline IT92KD-357-3 × Danilla & $2.38^{\mathrm{ns}}$ & $1.15^{\mathrm{ns}}$ & $1.00^{\mathrm{ns}}$ & $-0.28^{\mathrm{ns}}$ & $0.67^{\mathrm{ns}}$ & $0.42^{\mathrm{ns}}$ & $-0.15^{\mathrm{ns}}$ & $-0.42^{\mathrm{ns}}$ \\
\hline Tvu7778 $\times$ Danilla & $1.58^{\mathrm{ns}}$ & $0.58^{\mathrm{ns}}$ & $3.67^{\mathrm{ns}}$ & $-1.42^{\mathrm{ns}}$ & $-1.33^{\mathrm{ns}}$ & $1.67^{\mathrm{ns}}$ & $-0.08^{\mathrm{ns}}$ & $0.08^{\mathrm{ns}}$ \\
\hline IT93K-452-1 × Danilla & $4.75^{*}$ & $-1.00^{\mathrm{ns}}$ & $6.43^{*}$ & $1.50^{\mathrm{ns}}$ & $-0.67^{\mathrm{ns}}$ & $-4.53^{*}$ & $-0.92^{*}$ & $-1.25^{*}$ \\
\hline IT97K-499-35 × Danilla & $-6.07^{*}$ & $-0.17^{\mathrm{ns}}$ & $-5.25^{*}$ & $0.17^{\mathrm{ns}}$ & $2.83^{\mathrm{ns}}$ & $-7.17^{*}$ & $-0.62^{*}$ & $-0.25^{\mathrm{ns}}$ \\
\hline IT98K-205-8 × Danilla & $3.48^{*}$ & $-1.30^{\mathrm{ns}}$ & $-2.88^{\mathrm{ns}}$ & $-1.00^{\mathrm{ns}}$ & $6.55^{\mathrm{ns}}$ & $-3.60^{*}$ & $1.22^{*}$ & $-0.07^{\mathrm{ns}}$ \\
\hline IT98K-491-4 × Danilla & $-3.43^{*}$ & $-0.53^{\mathrm{ns}}$ & $-3.72^{\mathrm{ns}}$ & $11.85^{*}$ & $7.92^{\mathrm{ns}}$ & $-5.58^{*}$ & $0.08^{\mathrm{ns}}$ & $-0.32^{\mathrm{ns}}$ \\
\hline Tvu7778 × IT92KD-357-3 & $0.57^{\mathrm{ns}}$ & $-2.33^{\mathrm{ns}}$ & $-1.90^{\mathrm{ns}}$ & $-0.22^{\mathrm{ns}}$ & $2.42^{\mathrm{ns}}$ & $0.17^{\mathrm{ns}}$ & $0.05^{\mathrm{ns}}$ & $-0.42^{\mathrm{ns}}$ \\
\hline IT92KD-357-3 × IT93K-452-1 & $-1.58^{\mathrm{ns}}$ & $-0.42^{\mathrm{ns}}$ & $-5.17^{*}$ & $-1.50^{\mathrm{ns}}$ & $4.08^{\mathrm{ns}}$ & $-2.58^{*}$ & $0.50^{\mathrm{ns}}$ & $-0.25^{\mathrm{ns}}$ \\
\hline IT97K-499-35 × IT92KD-357-3 & $-1.25^{\mathrm{ns}}$ & $1.25^{\mathrm{ns}}$ & $0.03^{\mathrm{ns}}$ & $-4.60^{*}$ & $-3.58^{\mathrm{ns}}$ & $-4.17^{*}$ & $0.00^{\mathrm{ns}}$ & $-0.27^{\mathrm{ns}}$ \\
\hline IT98K-205-8 × IT92KD-357-3 & $-0.42^{\mathrm{ns}}$ & $-1.42^{\mathrm{ns}}$ & $-1.97^{\mathrm{ns}}$ & $-1.33^{\mathrm{ns}}$ & $0.75^{\mathrm{ns}}$ & $0.42^{\mathrm{ns}}$ & $0.12^{\mathrm{ns}}$ & $-0.17^{\mathrm{ns}}$ \\
\hline IT99K-513-21 × IT92KD-357-3 & $-2.83^{*}$ & $0.50^{\mathrm{ns}}$ & $1.83^{\mathrm{ns}}$ & $2.93^{\mathrm{ns}}$ & $9.00^{*}$ & $-2.05^{\mathrm{ns}}$ & $0.37^{\mathrm{ns}}$ & $0.00^{\mathrm{ns}}$ \\
\hline IT93K-452-1 × Tvu7778 & $24.65^{*}$ & $3.40^{*}$ & $9.38^{*}$ & $3.68^{\mathrm{ns}}$ & $19.08^{*}$ & $5.25^{*}$ & $0.57^{*}$ & $-0.03^{\mathrm{ns}}$ \\
\hline IT97K-499-35 × Tvu7778 & $8.07^{*}$ & $3.67^{*}$ & $-0.87^{\mathrm{ns}}$ & $-1.33^{\mathrm{ns}}$ & $6.42^{\mathrm{ns}}$ & $3.68^{*}$ & $0.63^{*}$ & $-0.25^{\mathrm{ns}}$ \\
\hline IT89KD-288 × Tvu7778 & $3.83^{*}$ & $-1.25^{\mathrm{ns}}$ & $3.88^{\mathrm{ns}}$ & $2.43^{\mathrm{ns}}$ & $-0.97^{\mathrm{ns}}$ & $0.97^{\mathrm{ns}}$ & $0.25^{\mathrm{ns}}$ & $-0.67^{\mathrm{ns}}$ \\
\hline IT99K-513-21 × Tvu7778 & $-2.00^{\mathrm{ns}}$ & $-1.85^{\mathrm{ns}}$ & $-1.78^{\mathrm{ns}}$ & $-5.62^{*}$ & $-1.33^{\mathrm{ns}}$ & $-1.63^{\mathrm{ns}}$ & $0.08^{\mathrm{ns}}$ & $-0.25^{\mathrm{ns}}$ \\
\hline IT97K-499-35 × Tvu12349 & $4.92^{*}$ & $0.00^{\mathrm{ns}}$ & $0.60^{\mathrm{ns}}$ & $-7.33^{*}$ & $6.33^{\mathrm{ns}}$ & $5.25^{*}$ & $1.25^{*}$ & $-0.25^{\mathrm{ns}}$ \\
\hline IT97K-499-35 × IT93K-452-1 & $-0.42^{\mathrm{ns}}$ & $-1.92^{\mathrm{ns}}$ & $-6.00^{*}$ & $-5.02^{*}$ & $-3.88^{\mathrm{ns}}$ & $4.13^{*}$ & $0.00^{\mathrm{ns}}$ & $0.07^{\mathrm{ns}}$ \\
\hline IT99K-513-21 × IT93K-452-1 & $0.00^{\mathrm{ns}}$ & $-3.08^{*}$ & $3.83^{\mathrm{ns}}$ & $-1.92^{\mathrm{ns}}$ & $4.33^{\mathrm{ns}}$ & $-2.58^{*}$ & $0.58^{*}$ & $0.25^{\mathrm{ns}}$ \\
\hline IT98K-205-8 × IT97K-499-35 & $3.15^{*}$ & $-0.57^{\mathrm{ns}}$ & $0.37^{\mathrm{ns}}$ & $3.43^{\mathrm{ns}}$ & $2.67^{\mathrm{ns}}$ & $2.13^{\mathrm{ns}}$ & $0.97^{*}$ & $0.83^{*}$ \\
\hline IT98K-491-4 × IT97K-499-35 & $-1.27^{\mathrm{ns}}$ & $-2.03^{\mathrm{ns}}$ & $-8.38^{*}$ & $-2.18^{\mathrm{ns}}$ & $16.43^{*}$ & $0.33^{*}$ & $-0.83^{*}$ & $-0.42^{\mathrm{ns}}$ \\
\hline IT99K-513-21 × IT98K-205-8 & $0.00^{\mathrm{ns}}$ & $-0.75^{\mathrm{ns}}$ & $4.50^{\mathrm{ns}}$ & $4.25^{*}$ & $2.08^{\mathrm{ns}}$ & $0.00^{*}$ & $0.22^{\mathrm{ns}}$ & $0.00^{\mathrm{ns}}$ \\
\hline S.E & 1.32 & 1.21 & 2.39 & 1.86 & 4.21 & 1.26 & 0.29 & 0.36 \\
\hline
\end{tabular}

*: significant; ns: not significant.

IT92KD-357-3 × IT99K-513-21, Tvu7778 × IT93K-452-1, Tvu12349 × IT97K-499-35, IT97K-499-35 × IT98K-205-8, and IT98K-205-8 × IT99K-513-21 were found to exhibit good combining ability as evident by high positive significant SCA effect in well-watered environment, while Danilla $\times$ IT93K-452-1, Danilla $\times$ IT97K-499-35, Danilla $\times$ IT98K-4914, IT92KD-357-3 × IT93K-452-1, IT92KD-357-3 × IT97K499-35, IT92KD-357-3 × IT99K-513-21, Tvu12349 × IT97K499-35, and IT98K-205-8 × IT99K-513-21 were found to be the best specific combiners for number of leaves per plant in water-stressed environment. The RCA effect for number of leaves per plant revealed crosses IT98K-205-8 $\times$ Danilla, IT98K-491-4 × Danilla, IT99K-513-21 × IT92KD357-3, IT93K-452-1 × Tvu7778, IT97K-499-35 × Tvu7778, IT97K-499-35 × Tvu12349, and IT98K-491-4 × IT97K-49935 to be highly positively significant in well-watered and IT93K-452-1 × Tvu7778, IT97K-499-35 × Tvu7778, IT97K499-35 × Tvu12349, and IT97K-499-35 × IT93K-452-1 in water-stressed environment. With respect to number of branches per plant, Danilla $\times$ IT93K-452-1, Danilla $\times$ IT98K205-8, Danilla $\times$ IT98K-491-4, IT92KD-357-3 × IT93K-4521, IT92KD-357-3 × IT98K-205-8, IT92KD-357-3 × IT99K513-21, Tvu7778 × IT93K-452-1, Tvu7778 × IT89KD-288, Tvu7778 × IT99K-513-21, Tvu12349 × IT97K-499-35, IT93K452-1 × IT99K-513-21, IT97K-499-35 × IT98K-491-4, and IT98K-205-8 $\times$ IT99K-513-21 were found to be significantly positive for SCA effect in well-watered environment, while
Danilla $\times$ IT93K-452-1, Danilla $\times$ IT97K-499-35, Danilla $\times$ IT98K-491-4, IT92KD-357-3 × IT93K-452-1, IT92KD-357-3 $\times$ IT99K-513-21, Tvu7778 × IT89KD-288, Tvu7778 × IT99K513-21, Tvu12349 × IT97K-499-35, IT93K-452-1 × IT99K-51321, IT97K-499-35 × IT98K-491-4, and IT98K-205-8 × IT99K513-21 were the best combiners in water-stressed environment. For RCA effect crosses, IT98K-205-8 × Danilla and IT97K-499-35 $\times$ Tvu12349 were significant in well-watered environment, while IT98K-205-8 × IT97K-499-35 was only significant in water-stressed environment.

Table 2 also showed analysis of variance for diallel cross and indicated significant difference for all traits. The genetic component of variance, additive (D), and dominance $\left(\mathrm{H}_{1}\right)$ were highly significant on both or either of the two environments for most of the traits studied (Table 6). The other components of variance $\mathrm{H}_{2}$ and $\mathrm{h}^{2}$ were also significant for most of the traits in the two environments. This suggested the presence of both additive and dominance effects in the inheritance of most of the traits studied.

For plant height, at six weeks as shown in Table 6, (D) component of variance was not significant in well-watered environment but significant in water-stressed environment. The dominance components of variance $\left(\mathrm{H}_{1}\right.$ and $\left.\mathrm{H}_{2}\right)$ were highly significant in both environments. This suggested the presence of both additive and dominance effects in the inheritance of this trait in both environments. However, a preponderance of dominance gene action was observed 


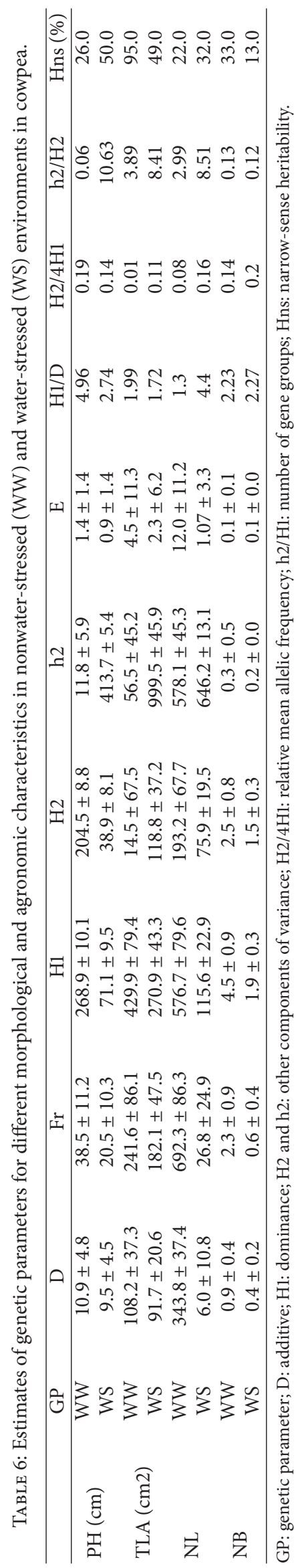


in the inheritance of this trait in both environments. This was further supported by the low estimates of narrow-sense heritability for this trait in both environments. A narrowsense heritability estimates of $26.0 \%$ and $50.0 \%$ indicated a below average proportion of variability due to additive gene action in plant height and an average proportion of variability in the inheritance of plant height could be due to nonadditive gene action. This further suggested rapid response to the breeding procedure for this trait. The ratio computed from genetic components provides useful information with regard to the degree, order, and direction of dominance. For plant height, the ratio $\left(\mathrm{H}_{1} / \mathrm{D}\right)^{1 / 2}$ suggested overdominance of genes for this trait in both environments. The F-component whose value indicates the proportion of dominant (+ sign) or recessive (- sign) alleles was significantly positive in waterstressed environment indicating gene asymmetry towards more dominant alleles for this trait in water stress. The ratio $\mathrm{H}_{2} / 4 \mathrm{H}_{1}$ estimates the relative mean allelic frequencies in the parents. The distribution of unequal gene frequencies in the parents was evidenced by a low value of $\mathrm{H}_{2} / 4 \mathrm{H}_{1}$ in both environments. The ratio $\mathrm{h}^{2} / \mathrm{H}_{2}$ estimates the number of gene groups exhibiting some dominance. The ratio suggested a minimum of one gene group showing dominance in wellwatered environment and minimum of two gene groups in water-stressed environment for plant height at six weeks.

For terminal leaflet area, the genetic components of variance, additive (D) and dominance $\left(\mathrm{H}_{1}\right)$, were highly significant for this trait in both environments. The other components of variance $\left(\mathrm{H}_{2}\right.$ and $\left.\mathrm{H}_{1}\right)$ were also significant in either of the environments. This suggested the presence of both additive and dominance effects in the inheritance of this trait. However, a preponderance of additive gene action was observed in the inheritance of this trait in well-watered environment. This was further supported by the high estimate of narrow-sense heritability $(90.0 \%)$ in well-watered environment and narrow-sense heritability was below average in the water-stressed environment $(49.0 \%)$. The average degree of dominance as indicated by the ratio $\left(\mathrm{H}_{1} / \mathrm{D}\right)^{1 / 2}$ suggested overdominance of this trait in both environments. The Fcomponent was significantly positive for this trait in both environments, indicating gene asymmetry towards more dominant alleles for this trait. The distribution of unequal gene frequencies in the parents was evidenced by a low value of $\mathrm{H}_{2} / 4 \mathrm{H}_{1}$ (less than 0.25 ) for this trait in both environments. The ratio $\mathrm{h}^{2} / \mathrm{H}_{2}$ suggested a minimum of two gene groups for this trait in both environments.

For number of leaves per plant, the genetic components of variance, additive (D) and dominance $\left(\mathrm{H}_{1}\right)$, were highly significant in well-watered environment for this trait, while dominance variance was highly significant in water-stressed environment. The other components of dominance $\left(\mathrm{H}_{2}\right.$ and $h^{2}$ ) were also significant in both environments. However, a preponderance of dominance gene action was observed in the inheritance of this trait in both environments. This was further supported by a below average of narrow-sense heritability for this trait in both environments. The average degree of dominance as indicated by the ratio $\left(\mathrm{H}_{1} / \mathrm{D}\right)^{1 / 2}$ suggested overdominance of a gene in both environments.
The F-component of variance was positively significant in well-watered environment, but not significant in waterstressed environment. This also indicates gene asymmetry towards more dominant alleles for this trait. The distribution of unequal gene frequencies in the alleles was evidenced by a low value of $\mathrm{H}_{2} / 4 \mathrm{H}_{1}$ less than 0.25 for this trait. The ratio $\mathrm{h}^{2} / \mathrm{H}_{2}$ estimates suggested a minimum of two gene groups for this trait in both environments.

For number of branches per plant, the genetic components of variance, the additive $(\mathrm{D})$ and dominance $\left(\mathrm{H}_{1}\right)$, were both significant in this trait in both environments. The other components of dominance, $\mathrm{h}^{2}$ and $\mathrm{H}_{2}$, were also significant in both environments. This suggested the presence of additive and dominance gene action in this trait in both environments. However, there was more of dominance gene action as indicated by a very low value of narrow-sense heritability in both environments. This indicated that nonadditive gene action played a significant role in the inheritance of this trait in both environments. The ratio $\left(\mathrm{H}_{1} / \mathrm{D}\right)^{1 / 2}$ suggested overdominance gene action in both environments. The Fcomponent of variance was positively significant in both environments. The distribution of unequal gene frequencies in the parents was evidenced by a low value of $\mathrm{H}_{2} / 4 \mathrm{H}_{1}$ of less than 0.25 for this trait in both environments. The ratio $h^{2} / \mathrm{H}_{2}$ suggested a minimum of one gene group showing dominance in both environments.

\section{Discussion}

In breeding programme, selecting superior genotypes is very essential as they can be used as parents in hybridization (Kadam et al. [16]). In this context, the concept of combining ability is becoming important in plant breeding particularly in breeding for the drought-tolerant trait. Analysis of variance for parents, $F_{1}$ and $\mathrm{RF}_{1}$, showed significant differences for all the traits. Similarly, the differences among hybrids were also significant for all the studying traits. It indicates the presence of diversity among the material in both environments. There were significant differences between $\mathrm{F}_{1^{\text {s }}}$ versus parents and $\mathrm{RF}_{1}$ versus parents for all the studying traits in both environments, except for the number of branches per plant in water-stressed environment. This suggests that there was wider genetic variability existing among the studying material. Previous research shows that variations for drought tolerance exist in various crops species like wheat and maize (Muchero et al. [21] and Chiulele et al. [22]). Analysis of variance for combining abilities showed highly significant differences in both general combining ability (GCA) and specific combining ability (SCA) of the cowpea parents studied indicating the importance of both additive and nonadditive gene effects in their inheritance in either or both nonwaterstressed and water-stressed environments. The estimated variances due to specific combining ability were higher than general combining ability indicating the predominance of the nonadditive gene action in these traits in either or both environments. This report is also in agreement with Bhavesh Patel et al. [23] and Selvarkumar et al. [24], but in contrast to Ayo-Vaughan et al. [25]. The estimates of predictability 
ratio less than unity in these traits suggest that performance of hybrids for these traits could be difficult to predict on the basis of general combining ability of parents due to the importance of dominance. However, nonadditive gene action due to dominance and/or epistasis, as revealed by significant SCA mean squares, contributed more to the total genetic variability observed in these traits. Gupta et al. [26], however, assumed that the presence of nonadditive gene effect could reduce the progress expected from early generation selection. Kang [27], however, suggested the use of the ratio of GCA to SCA sums of the square to determine the direction of genetic control of traits and the breeding value of genotypes. The value of approximately one obtained for all the traits in this study shows that the traits are highly heritable and that the additive gene effects were equally important in the inheritance of these traits (Amiri-Oghan et al. [28]).

Generally, the value of the general combining ability effect in nonwater-stressed is higher than water-stressed environment indicating the effects of the environmental factor and or dominance under water stress.

The estimate of GCA and SCA effects of 10 parents and 42 hybrids for four quantitative traits studied showed the importance of both additive and nonadditive gene action in the inheritance of these traits but however reflected the preponderance of nonadditive gene effect. This indicated that the selection for the superior hybrids should be delayed to the advanced generations. In general, parent IT97K-49935 expressed significant GCA effect for all the characters. Parents TVU12349, IT89KD-288, and IT98K-491-4 are generally poor combiners for all the characters as expressed by significant negative value. Hence, the parents with significant GCA effects could be used in an intensive breeding program to exploit both additive and nonadditive components of variation and might have contributed a maximum number of favorable genes and possible allelomorphs (Baker 1978 [29]; Ojo 2005 [30]; Gouri Shankar [31]). The importance of both additive and nonadditive genetic variance in almost all traits among the genotypes evaluated could be exploited to an advantage by using the conventional breeding methods, such as pedigree or pure line selections (Rupela and Johansen [32]).

Some of the significant crosses performed well in both environments, while some were significant only in a particular environment. However, most of the significant crosses also involved at least one good general combiner's parent which indicated the presence of additive $x$ additive and additive $\times$ dominance gene interactions. Few crosses also involved two best general combiners (e.g., Danilla $\times$ IT97K-499_35); this indicated the importance of additive and additive $\times$ additive gene action in the inheritance of these traits and also indicated rapid genetic progress in advanced generations under water stress. Daniel et al. [33] reported that the hybridization between two good general combiners may be governed by additive $\times$ additive gene actions which might elicit transgressive segregants in the advanced generations for the traits, thus producing hybrids with good specific combining ability.

The crosses that exhibit low GCA effects but exhibit high SCA effects suggest the presence of epistatic gene action. It may also suggest gene dispersion and genetic interaction between favorable alleles contributed by both parents (Adeniji and Kehinde [34]). Crosses with a negative SCA estimate indicate a partial dominance (Ojo [30]).

The analysis of genetic components of variance suggested both the additive variance (D) and dominance variance $\left(\mathrm{H}_{1}\right)$ to be significant for all the studying traits in both environments, indicating that the expression of all the traits is conditioned by both additive and dominance gene actions. However, dominance component $\left(\mathrm{H}_{1}\right)$ was more predominant than additive component (D). The proportion of dominant genes $\mathrm{H}_{2} / 4 \mathrm{H}_{1}$ with positive or negative effects in parents was less than 0.25 for all the traits in both environments suggesting the asymmetrical distribution of positive and negative dominant genes in parents (Adeniji and Kehinde [34]; Amiri-Oghan et al. [28]). Asymmetrical distribution of dominant and recessive alleles in parents was also indicated by the direction (sign) and degree of F-component which was positive and more than zero for all traits under study, indicating that dominant alleles are more frequent than recessive alleles in both environments. When this value is equal to 0.25 then the genes are equally distributed among the parents. The mean degree of dominance $(\mathrm{H} 1 / \mathrm{D})^{1 / 2}$ was more than one which ranged from 1.30 to 4.96 for all the traits in both environments, suggesting the prominence of overdominance gene action. The relative proportion of dominant and recessive alleles was more than one for terminal leaflet area and number of leaves per plant in both environments indicating the excess of dominant alleles and the minority of recessive alleles for these traits. The value of $\mathrm{h}^{2}$ was significant in both environments for number of leaves per plant showing the presence of overall dominant gene effect under study but was significant for plant height and terminal leaflet area only in water-stressed environment. The ratio $h^{2} / \mathrm{H}_{2}$ revealed the different number of genes controlling the four traits. This study indicated a minimum of ten genes for plant height in water-stressed environment, and minimum of three and eight genes for terminal leaflet area and number of leaves per plant in well-watered and water-stressed environments, respectively, thus revealing that their polygenic inheritance is a characteristic of quantitative traits. The environment component (E) was not significant for all the traits.

These were further supported by the low estimates of narrow-sense heritability of 0.26 and 0.50 in plant height in both environments; 0.49 for terminal leaflet area in waterstressed environments; 0.22 and 32 for number of leaves per plant in both environments. This observation could be due to nonadditive gene action. In some cases, it could suggest a rapid response to the breeding procedure or the trait involved was being highly influenced by an environmental factor or it could be an indication of overdominance situation of dominant alleles. Hence selection for these traits should be delayed till later generations to reduce the effect of dominance. A preponderance of additive gene action was also observed in the inheritance of terminal leaflet in well-watered environment. High narrow-sense heritability indicated that this trait was least influenced by environmental effect and can easily be transmitted through hybridization. 
In summary, the cowpea traits studied were controlled by both additive and nonadditive gene action, however, with a preponderance of nonadditive gene action in wellwatered and water-stressed conditions. Because of the importance of dominance gene effect in the inheritance of these traits, improvement for these traits will, therefore, require a recurrent selection procedure to allow for favorable gene recombination in later generations in both environments. Danilla, IT93K-432-1, and IT97K-499-35 with relatively large, positive, and significant GCA effects could be used as parents with desirable genes for genetic improvement of the considered yield components in cowpea. Also, Danilla $\times$ IT97K499-35 appeared to be the best specific combiners for all the traits in this study.

The narrow-sense heritability ranged from $13.0 \%$ for number of branches per plant in water-stressed to $95.0 \%$ in well-watered environments for terminal leaflet area, suggesting the possibility of improvement in some of these traits in both environments.

\section{Conflicts of Interest}

The authors declare that they have no conflicts of interest.

\section{References}

[1] A. Baghizadeh, A. Taleei, and E. Ghasemi, "Evaluation of genetic variability for yield and some of quantitative traits inIran cowpea collection," Agriculture and Biology Journal of North America, vol. 1, no. 4, pp. 625-629, 2010.

[2] A. E. Hall, B. B. Singh, and I. D. Ehlers, "Cowpea breeding," Plant Breeding Reviews, vol. 15, pp. 215-274, 1997.

[3] H. Valenzuela and J. Smith, "Cowpea. Sustainable agriculture, green manual crops," College of Tropical Agriculture and Human Resources (CTAHR), 2002.

[4] J. T. Noubissié, E. Youmbi, N. Y. Njintang, A. N. Alladoum, M. R. Nguimbou, and J. M. Bell, "Genetic architecture of some leaf yield and quality attributes in dual-purpose Cowpea (Vigna unguiculata L. Walp.)," American Journal of Experimental Agriculture, vol. 1, no. 4, pp. 400-413, 2011.

[5] J. Abadassi, "Cowpea (Vigna unguiculata (L.) Walp.) agronomic traits needed in tropical zone," International Journal of Pure \& Applied Bioscience, vol. 3, no. 4, pp. 158-165, 2015.

[6] D. Diouf, "Recent advances in cowpea [Vigna unguiculata (L.) Walp.] "omics" research for genetic improvement," African Journal of Biotechnology, vol. 10, no. 15, pp. 2803-2810, 2011.

[7] FAOSTAT, 2015. FAO Statistics Division 20015.

[8] FAOSTAT, 2008. FAO Statistics Division 2008.

[9] J. Quinn and R. Myers, Cowpea. Alternatives Crops Guide, Thomas Jefferson Agricultural Institute, Columbia, Mo, USA, 2002.

[10] H. Shimelis and R. Shiringani, "Variance components and heritabilities of yield and agronomic traits among cowpea genotypes," Euphytica, vol. 176, no. 3, pp. 383-389, 2010.

[11] M. Hayatu, S. Y. Muhammad, and U. A. Habibu, "Effect of water stress on the leaf relative water content and yield of some Cowpea (Vigna Unguiculata (L) Walp.) Genotype," International journal of Scientific Technology Research, vol. 3, no. 7, 2014.

[12] R. J. Summerfield, J. S. Pate, E. H. Roberts, and H. C. Wien, "The physiology of cowpea," in Cowpea Research, Production and
Utilization, S. R. Singh and K. O. Rachie, Eds., pp. 66-101, Chichester John Wiley, 1985.

[13] IITA, "Challenges and opportunities for enhancing sustainable cowpea production," 2000.

[14] M. Ishiyaku and H. Aliyu, "Field evaluation of cowpea genotypes for drought tolerance and striga resistance in the dry savanna of the North-West Nigeria," International Journal of Plant Breeding and Genetics, vol. 7, no. 1, pp. 47-56, 2013.

[15] A. P. Hira Lal, D. B. Mathura Rai, N. Bhar dwai, R. Nath, and V. Nath, "Combining ability of quantitative characters cowpea (Vigna unguiculata (L.) Walp). Short communication," Vegetable Science, vol. 36, no. 2, pp. 265-267, 2009.

[16] Y. R. Kadam, A. I. Patel, P. P. Chaudhari, J. M. Patel, and S. J. More, "Combining ability in vegetable cowpea (Vigna unguiculata (L.) Walp," Crop Research, vol. 45, no. 1, 2, 3, pp. 196-201, 2013.

[17] B. A. Rojas and G. F. Sprague, "A comparison of variance components in corn yield trials-111. General and specific combining ability and their interactions with locations and years," Agronomy Journal, vol. 44, no. 9, p. 462, 1952.

[18] B. Griffing, "Concepts of general and specific combining ability in relation to diallel crossing system," Australian Journal of Biological Sciences, pp. 463-493, 1956.

[19] B. L. Hayman, "The theory and analysis of diallel crosses," Genetics, vol. 39, pp. 789-809, 1954.

[20] R. Aksel and C. P. V. Johnson, "Analysis of diallel crosses: A worked example," Advancing Frontiers of PL. Sciences, pp. 3753, 1963.

[21] W. Muchero, J. D. Ehlers, and P. A. Roberts, "Seedling stage drought-induced phenotypes and drought-responsive genes in diverse cowpea genotypes," Crop Science, vol. 48, no. 2, pp. 541$552,2008$.

[22] R. M. Chiulele, G. Mwangi, P. Tongoona, J. D. Ehlers, and A. D. Ndeve, "Assessment of cowpea genotypes for variability to drought tolerance," African Crop Science Conference Proceedings, vol. 10, pp. 531-537, 2010.

[23] N. Bhavesh Patel, R. T. Desai Bhavin, N. Patel, and P. B. Kuladiya, "Combining ability study for seed yield in cowpea (Vigna unguiculata (L.) Walp)," The Biosean (An International Journal of Life Sciences), vol. 8, no. 1, pp. 139-142, 2013.

[24] G. Selvarkumar, C. R. Anarndakumar, C. Chinnich, and R. Ushakumari, "Combining ability analysis in the inter-subspecific crosses of cowpea (Vigna unguiculata (L.) Walp) and yard long bean (Vigna unguiculata (L.) Walp) pp. Sesquipedlis)," Electronic Journal of Plant Breeding, vol. 5, no. 2, 2014.

[25] M. A. Ayo-Vaughan, O. J. Ariyo, and C. O. Alake, "Combining ability and genetic components for pod and seed traits in cowpea lines," Italian Journal of Agronomy, vol. 8, no. 2, pp. 7378, 2013.

[26] V. P. Gupta, R. K. Kapila, V. K. Sood, and N. D. Rana, "Predicting transgression on the basis of combining ability and heterosis in soybean," Journal of Crop Improvement, vol. 20, pp. 143-150, 1993.

[27] M. S. Kang, Applied Quantitative Genetics, M. S. Kang, Baton Rouge, La, USA, 1994.

[28] H. Amiri-Oghan, M. H. Fotokian, F. Javidfar, and B. Alizadeh, "Genetic analysis of grain yield, days to flowering and maturity in oilseed rape (Brassica napus L.) using diallel crosses," International Journal of Plant Production, vol. 3, no. 2, pp. 19-26, 2009.

[29] R. J. Baker, "Issues in a diallel analysis," Crop Science, vol. 18, pp. 533-536, 1978. 
[30] D. K. Ojo, "Inheritance pattern and genetics of seed coat color and seed size in a tropical soybean (Glycine max (L) Merr) cross," in Journal of Genetics and Breeding, vol. 59, pp. 173-178, Department of Plant Breeding \& Seed Technology, University of Agriculture, Ogun State, Nigeria, 2005.

[31] V. Gouri Shankar, M. Ganesh, A. R. G. Ranganatha, V. Sridhar, and A. Suman, "Combining ability and heterosis studies with diverse cytoplasmic male sterility sources in sunflower (Helianthus annuus L.)," Journal of Genetics and Breeding, vol. 59, pp. 313-320, 2005.

[32] O. P. Rupela and C. Johansen, "Identification of non-nodulating, and low and high nodulating plants in pigeonpea," Soil Biology and Biochemistry, vol. 27, no. 4-5, pp. 539-544, 1995.

[33] I. O. Daniel, H. T. Oloyede, O. T. Adeniji, D. K. Ojo, and A. E. Adegbite, "Genetic analysis of earliness and yield in elite parental lines and hybrids of tropical maize (Zea mays L.)," Journal of Genetics and Breeding, vol. 60, pp. 289-296, 2006.

[34] O. T. Adeniji and O. B. Kehinde, "Diallel analysis of pod yield in West African Okra (Abelmoschus caillei [A. chev]) stevels," Journal of Genetics and Breeding, vol. 57, no. 3, pp. 291-294, 2003. 


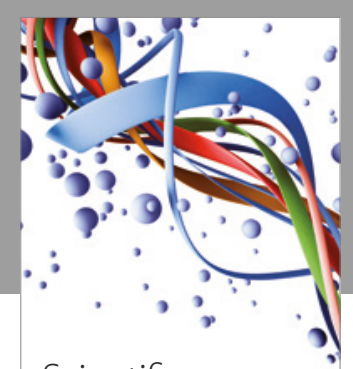

Scientifica
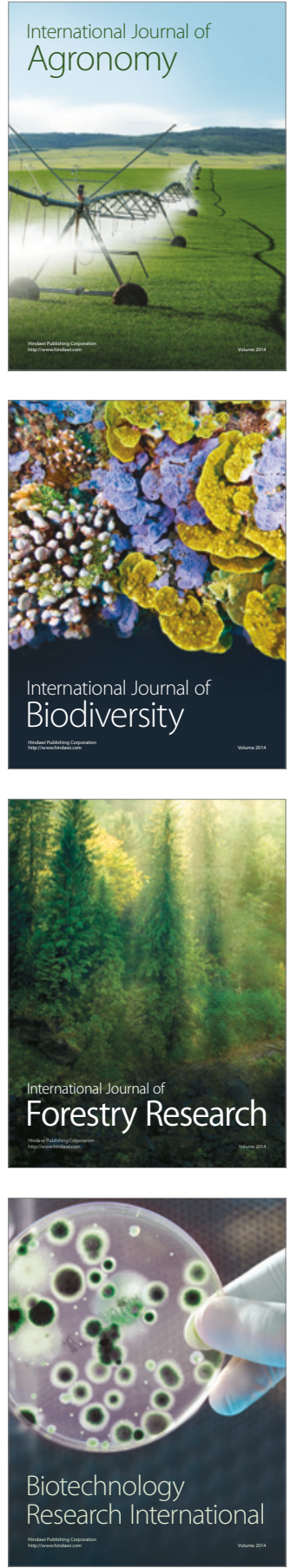
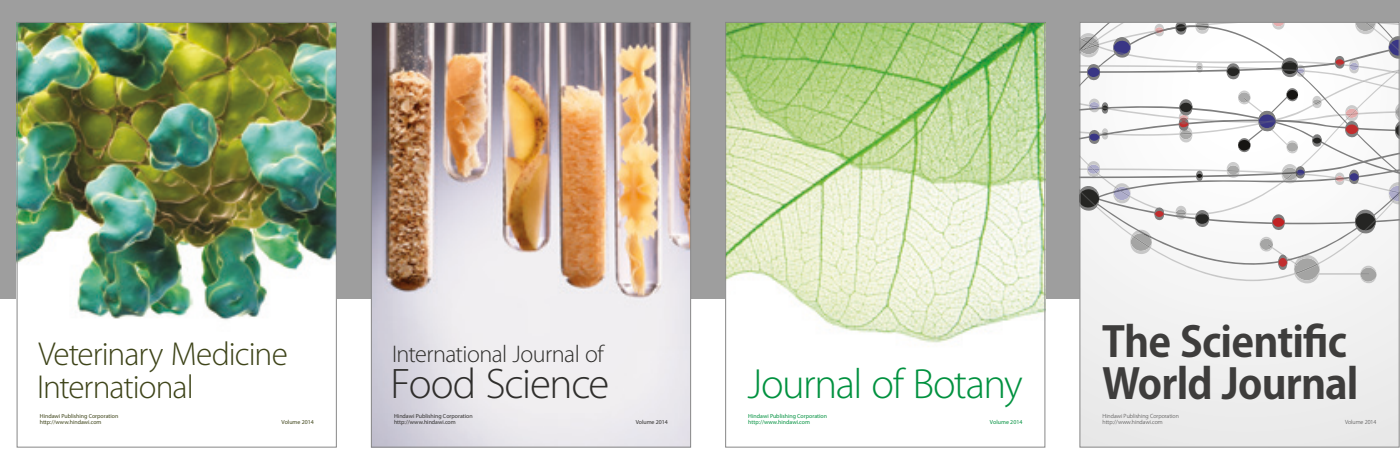

The Scientific

\section{World Journal}

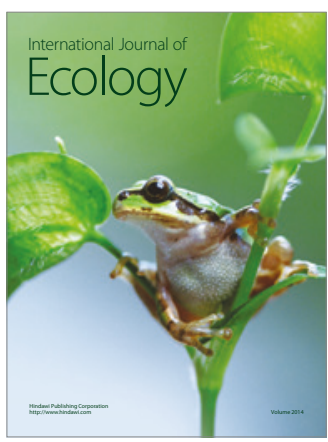

\section{Hindawi}

Submit your manuscripts at

https://www.hindawi.com
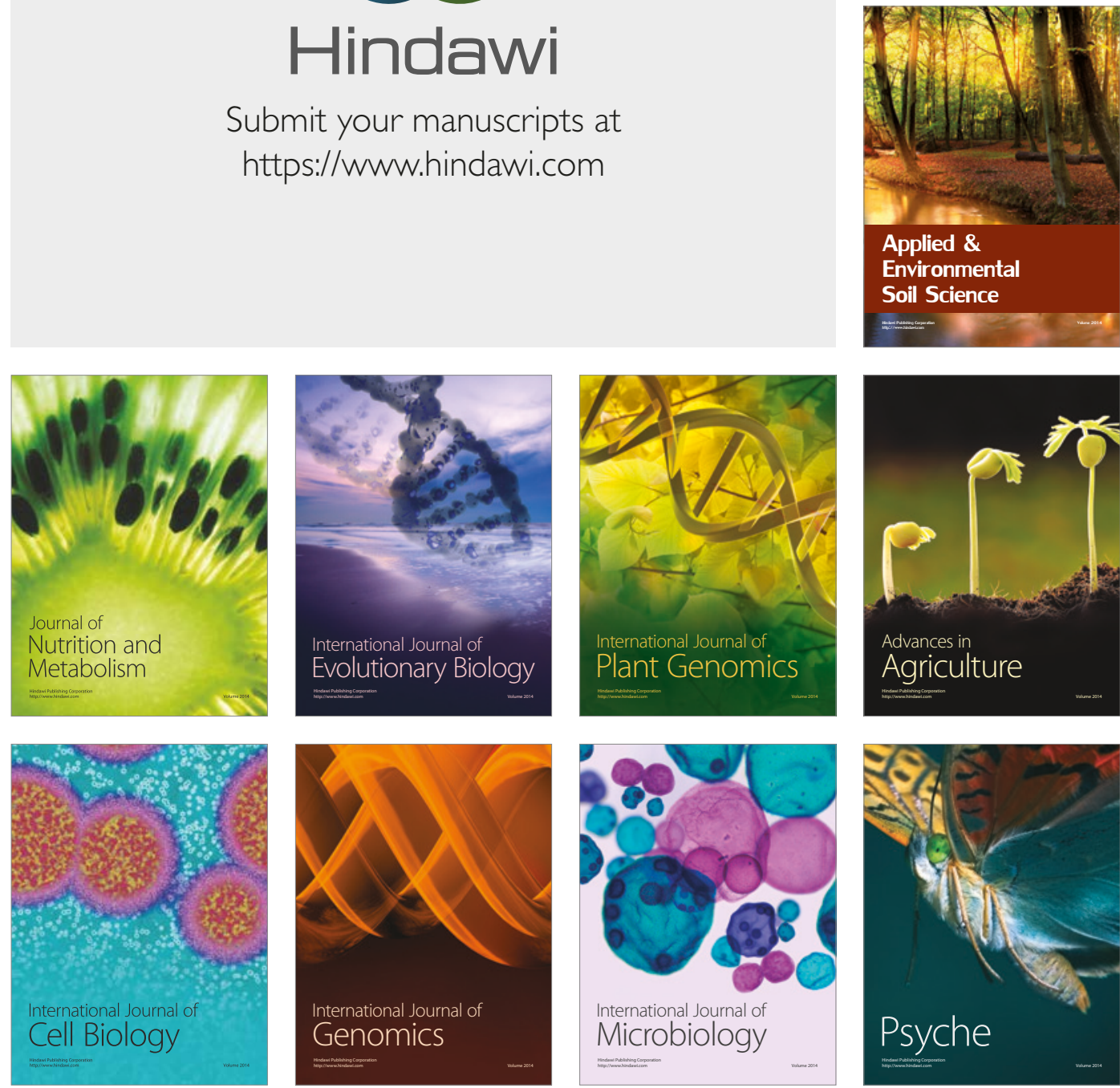

hternational Journal of Microbiology
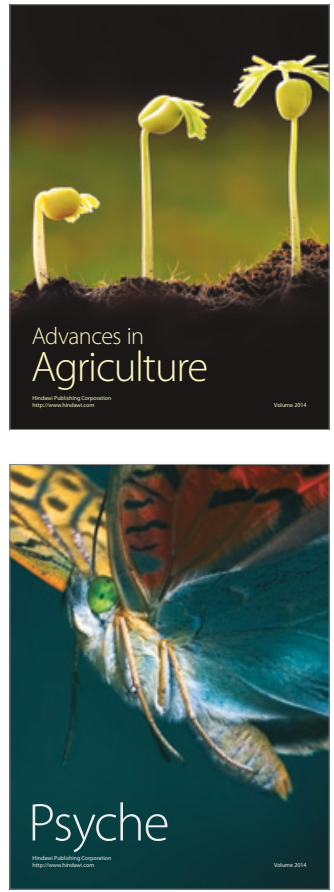